\title{
Spatial Distribution of Water Quality and Load Units in the Iinashi River Basin, Shimane Prefecture, Japan
}

\author{
Hiroaki Somura*,1, Daisuke Nakayama $^{2}$, Morihiro Aizaki ${ }^{1}$, Yasushi Seike ${ }^{3}$, Minoru Okumura ${ }^{3}$ and \\ Kumiko Nishikata ${ }^{1}$
}

\author{
${ }^{1}$ Faculty of Life and Environmental Science, Shimane University, Matsue 690-8504, Japan \\ ${ }^{2}$ Research Center for Coastal Lagoon Environment, Shimane University, Matsue 690-8504, Japan \\ ${ }^{3}$ Interdisciplinary Faculty of Science and Engineering, Shimane University, Matsue 690-8504, Japan
}

\begin{abstract}
The spatial distributions of water quality and load units were determined for each small sub basin of the Iinashi River basin as a first step in water environment management. In addition, a GIS database was established to comprehensively resolve the issue of water quality degradation. It was found the concentrations of water quality parameters in the Iinashi River basin were relatively low at almost all sampling points. The average concentrations of each parameter are $1.86 \mathrm{mg} \cdot \mathrm{L}^{-1}$ of chemical oxygen demand, $0.73 \mathrm{mg} \cdot \mathrm{L}^{-1}$ of dissolved organic carbon, $18.5 \%$ of biodegradation ability, $6.58 \mathrm{mg} \cdot \mathrm{L}^{-1}$ of silica, $519.8 \mu \mathrm{gN} \cdot \mathrm{L}^{-1}$ of total nitrogen, and $27.4 \mu \mathrm{gP} \cdot \mathrm{L}^{-1}$ of total phosphorus. In addition, the load units discharged from the small watersheds were obtained. The load units varied greatly regardless of similar land use in the basin. Moreover, discharged loads from observation point 1-31 in the Yamasa River basin were higher than those from observation point 1-5 in the upstream of the Iinashi River basin regardless of high percentage of forest area (91.51\%), low percentage of agricultural land $(2.3 \%)$ and low population density $\left(24\right.$ people $\mathrm{km}^{-2}$ ). Finally, the discharged loads from observation point 1-3 were determined as $53.2 \mathrm{~g} \cdot \mathrm{ha}^{-1} \cdot \mathrm{day}^{-1}$ of suspended solid, $45.4 \mathrm{~g} \cdot \mathrm{ha}^{-1} \cdot \mathrm{day}^{-1}$ of chemical oxygen demand, $20.9 \mathrm{~g} \cdot \mathrm{ha}^{-1} \cdot \mathrm{day}^{-1}$ of dissolved organic carbon, $8.1 \mathrm{~g} \cdot \mathrm{ha}^{-1} \cdot \mathrm{day}^{-1}$ of particulate organic carbon, $16.3 \mathrm{~g} \cdot \mathrm{ha}^{-1} \cdot \mathrm{day}^{-1}$ of total nitrogen, $5.0 \mathrm{~g} \cdot \mathrm{ha}^{-1} \cdot \mathrm{day}^{-1}$ of dissolved organic nitrogen, 1.3 $\mathrm{g} \cdot \mathrm{ha}^{-1} \cdot \mathrm{day}^{-1}$ of particulate organic nitrogen, and $0.3 \mathrm{~g} \cdot \mathrm{ha}^{-1} \cdot \mathrm{day}^{-1}$ of total phosphorus.
\end{abstract}

Keywords: Water environment management, Lake Nakaumi, GIS, non-point sources.

\section{INTRODUCTION}

Integrated management of the water environment from river basins to downstream areas such as lakes is very important in conservation and the sustainable use of resources. In recent years, there has been an attempt to improve the water quality in lakes by establishing adequate sewage systems and creating legislation so that pollutant loading to lakes and rivers meets environmental standards. However, the water quality has not improved as much as expected. One of the reasons is considered to be pollutant loads discharging from non-point sources such as agricultural land.

Load units from non-point sources such as paddy fields, upland fields, forests and urban areas are important in that they are used to estimate the impact of currently considered conservation methods on downstream areas and lakes. However, these values are too difficult to determine with certainty because pollutant loads from non-point sources are affected by the conditions of sites and precipitation (Takeda, 2001). In addition, as a load unit is defined by one constant value or one equation for one land use, it is very difficult to consider a detailed plan for the protection of downstream and lake environments. Furthermore, few studies have been done on the load units of divided small watersheds. Thus, it is very important to present information on the load units for small watersheds flowing into a target site.

*Address correspondence to this author at the Faculty of Life and Environmental Science, Shimane University, Matsue 690-8504, Japan;

E-mail: som-hiroaki@life.shimane-u.ac.jp
The water quality of Lake Shinji and Lake Nakaumi in Shimane Prefecture, Japan, has not improved greatly. Lake Shinji and Lake Nakaumi were designated as one of the Wetlands of International Importance by the Ramsar Convention in November 2005.

Many researchers have studied the water quality of Lake Shinji and Lake Nakaumi from several perspectives (e.g. Seike et al. 2006; Sakuno et al. 2003; Nonaka et al. 2003; Senga et al. 2001; Sakuno et al. 1998). In addition, there have been studies on the Hii River, which accounts for about $70 \%$ of the total catchment area of Lake Shinji (e.g. Takeda et al. 1996; Ishitobi et al. 1988). However, there have been few studies on the water environment of rivers flowing into Lake Nakaumi. One of the rivers is the Iinashi River that accounts for about $30 \%$ of the total catchment area of Lake Nakaumi. When considering watershed management and the improvement of the water environment in lakes, information for both lakes and rivers is necessary. Thus, we attempt to produce a Geographic Information System (GIS) database for point and non-point sources and investigate the Iinashi River basin to understand the spatial distribution of water quality and load units for small watersheds that make up the larger basin as a first step in water environment management.

\section{STUDY AREA}

The Iinashi River basin is located in the eastern part of Shimane Prefecture, Japan (Fig. 1). The river flows from Mt. Tamamine. The catchment area is about $210 \mathrm{~km}^{2}$ and the length of the river is about $40 \mathrm{~km}$. The river flows through Yasugi City and then into Lake Nakaumi, which is a promi- 
nent brackish water lake. The river basin has two reservoirs: the Fube and Yamasa dams. The dams are sources of drinking water for the cities of Matsue and Yasugi and the town of Higashi Izumo. Forest is dominant in the area. Over $80 \%$ of the area is forest and only $6 \%$ is used for agriculture.

Along the downstream of the Iinashi River, the Tayori River flows to Lake Nakaumi. Tayori River is an agricultural drainage river with a catchment area of about $12 \mathrm{~km}^{2}$. It is very difficult to distinguish the Iinashi River and Tayori River basins because of the complexity of their drainage, and thus the investigation was conducted for the rivers combined.

\section{METHODS}

\subsection{Field Investigation and Water Quality Analyses}

A field investigation was conducted on the $5^{\text {th }}$ of August 2006 by three groups. The weather was fine but record heavy rain of about $250 \mathrm{~mm}$ over two days had fallen on the inves- tigation site two weeks previous. One group investigated the upper main stream, another group investigated the branch of the river (Yamasa River basin), and the last group surveyed the downstream of the river. Flow velocities and river cross sections were measured to calculate water volume, and river water was sampled to analyze water quality. Water samples at dam reservoirs were collected with a Van Dorn type sampler of $3 \mathrm{~L}$ capacity, at about $0.5 \mathrm{~m}, 3 \mathrm{~m}$, and $10 \mathrm{~m}$ from the surface. Multiple water quality sensors (Hydrolab MS4a, Hydrolab Quanta, Horiba U-21XD) were used to measure water temperature, dissolved oxygen (DO) concentration, and electrical conductivity (EC). There was a total of $30 \mathrm{ob}-$ servation points.

Water quality was analyzed immediately after the field investigation in laboratories. Suspended solid (SS) was immediately filtered through glass fiber-filters (Whatman $\mathrm{GF} / \mathrm{F})$ preignited at $450{ }^{\circ} \mathrm{C}$. Particulate organic carbon (POC) and particulate organic nitrogen (PON) concentrations were determined using a YANACO MT-5 type CHN

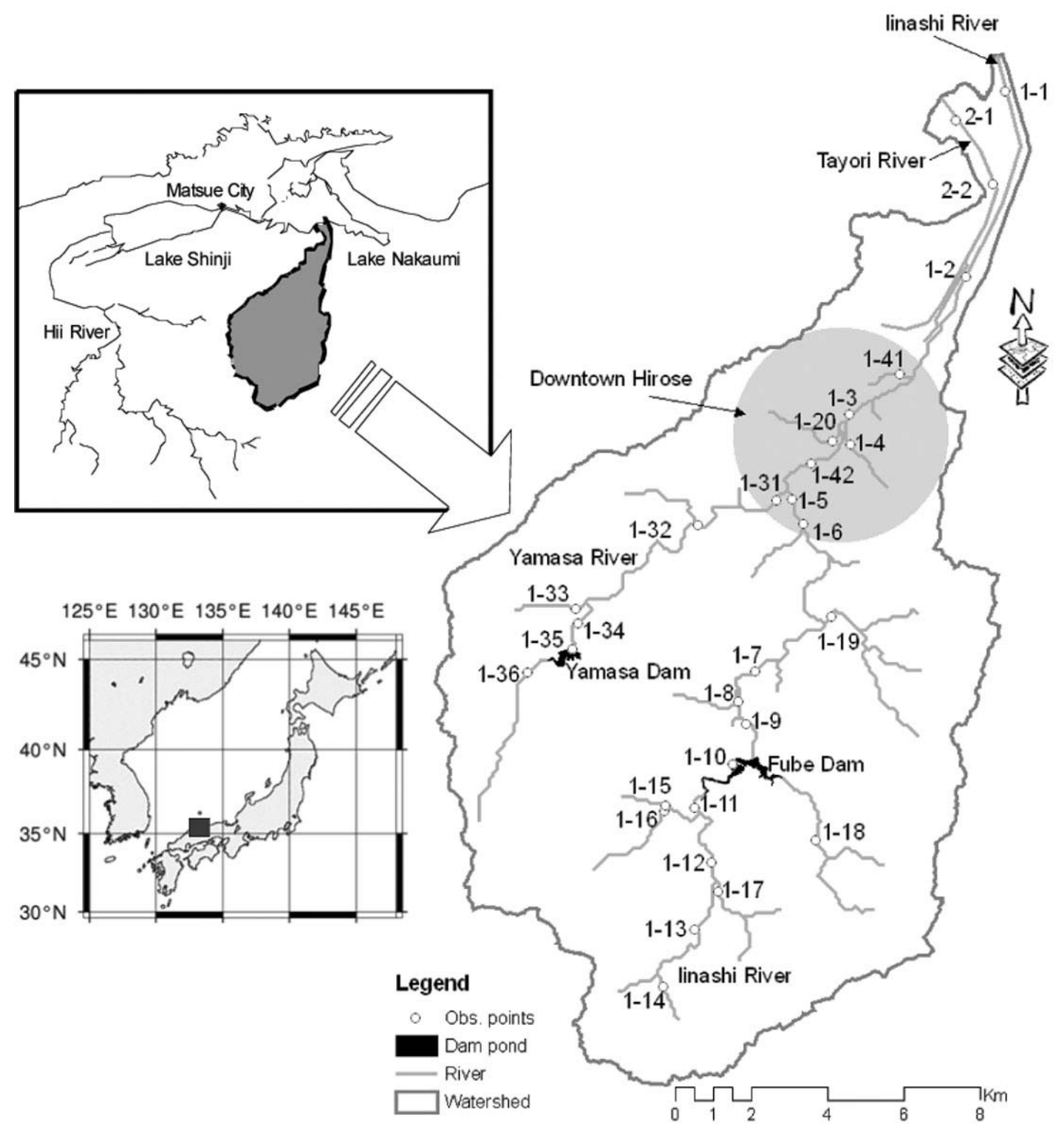

Fig. (1). Location of the Iinashi River Basin. 
analyzer. The chlorophyll-a (Chl- $a$ ) concentration was determined by the SCOR/UNESCO method (1966). Alkalinity was determined using a method presented in Limnological Analysis (Saijo \& Mitamura, 1995). The dissolved organic carbon (DOC) concentration was determined using a total organic carbon analyzer (SHIMADZU TOC- $\mathrm{V}_{\mathrm{CSN}}$ ). Biodegradation ability (BD) was determined using the same method as for DOC with samples stored for 100 days in a constant condition $\left(20{ }^{\circ} \mathrm{C}\right.$ and shielded). The chemical oxygen demand (COD) was measured using the potassium permanganate method (JIS K 0102). The Ammonia $\left(\mathrm{NH}_{4}\right)$ concentration was determined using the indophenol method (Sagi, 1966). Nitrite $\left(\mathrm{NO}_{2}\right)$ and nitrate $\left(\mathrm{NO}_{3}\right)$ concentrations were determined using the methods of Bendscheider \& Robinson (1952) and Wood et al. (1967), respectively. The total nitrogen (TN) concentration was measured with a nitrogen analyzer (Mitsubishi Kagaku model TN-05). The phosphate $\left(\mathrm{PO}_{4}\right)$ concentration was determined by the method of Murphy \& Riley (1962). The total phosphorus (TP) concentration was determined by the method of Menzel \& Corwin (1965). Dissolved organic nitrogen (DON) and dissolved organic phosphorus (DOP) concentrations were calculated from the relationship between dissolved organic and inorganic carbon. Colon bacillus was detected using a method of JIS K 0102. Cation concentrations such as those of iron (Fe), calcium $(\mathrm{Ca})$, magnesium $(\mathrm{Mg})$, and manganese $(\mathrm{Mn})$ were determined by inductively coupled plasma (ICP) emission spectrometry (SHIMADZU ICPS-2000). The silica (Si) concentration in the filtrate was determined by ICP emission spectrometry. Anion concentrations such as those of chlorine $(\mathrm{Cl})$ and sulfuric acid $\left(\mathrm{SO}_{4}\right)$ were determined by ion chromatography (DIONEX DX-120).

\subsection{GIS Data Development}

GIS data were found for the basin using existing statistical data and considering emission control measures from non-point sources. Details of the GIS data are shown in Table 1. To develop the GIS, national spatial data of the infrastructure of the river and reservoirs, population data, forest data, a topographical map and aerial photographs were prepared as the existing datasets. Using these datasets, the survey points, watershed, agricultural areas, residential areas and moorland areas were developed in the GIS. The Iinashi River basin was divided into 31 sub-basins using the locations of observation points and the topographical map. Wherever it was difficult to determine the watershed, a sub basin was determined by terrain analysis. In addition, the forested area in each sub-basin was calculated using data from the Shimane Forest information station. Moreover, agricultural, residential and moorland areas were tabulated for each sub basin after land use units were subediting using the aerial photographs. Population data for each sub basin was estimated from village data. Population data for the Tayori

Table 1. GIS Data Information Established in the Basin

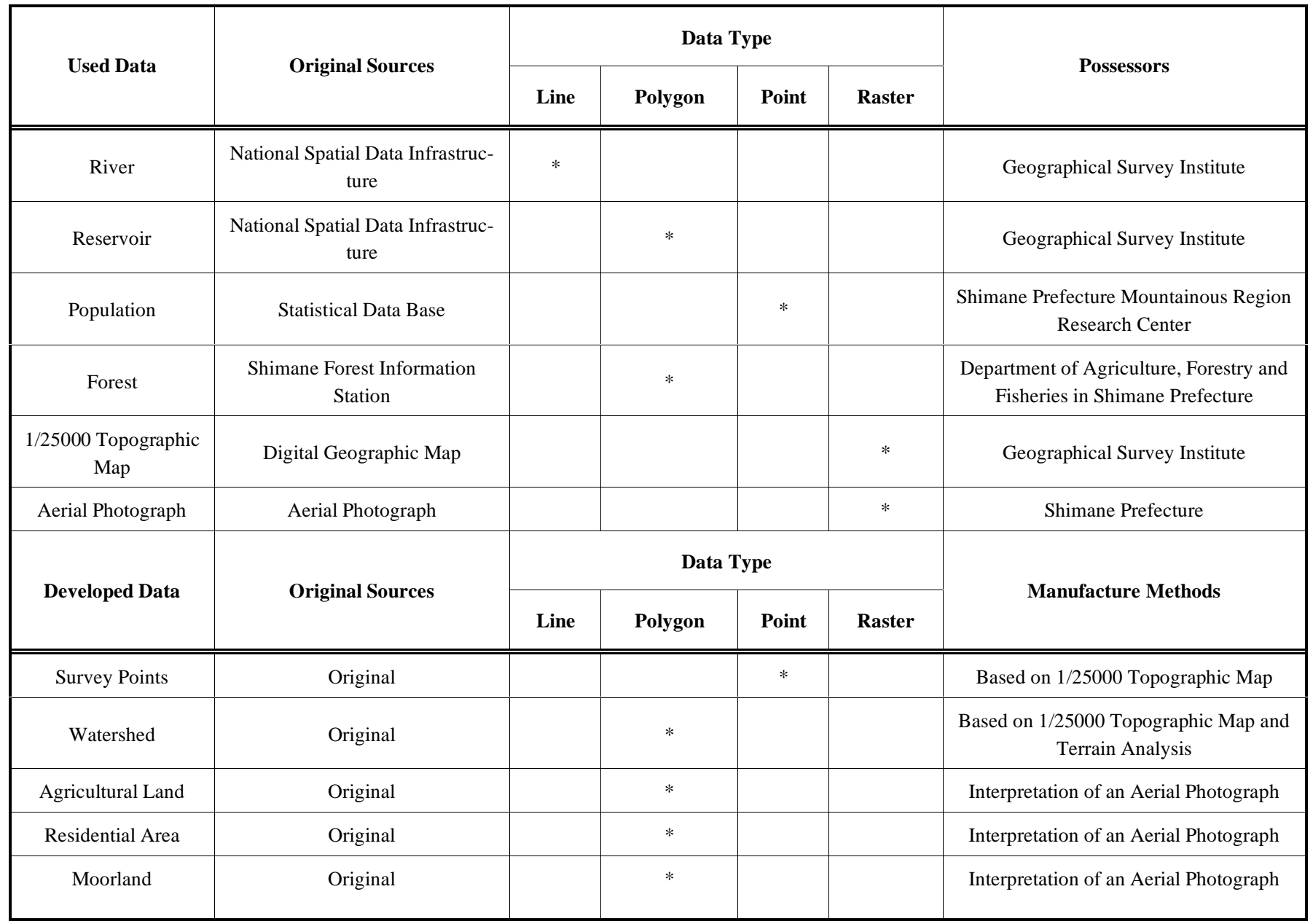


Table 2. Water Quality at Fube and Yamasa Dams

\begin{tabular}{|c|c|c|c|c|c|c|c|c|c|c|}
\hline & 0.5 & 27.8 & 9.9 & 9.0 & 2.0 & 4.9 & 32.8 & 1.3 & 473.9 & 15.7 \\
\hline \multirow[t]{2}{*}{ Fube } & 3 & 24.7 & 9.8 & 9.6 & 2.7 & 6.9 & 23.9 & 1.4 & 516.9 & 19.2 \\
\hline & 0.5 & 26.5 & 8.2 & 7.9 & 1.5 & 2.7 & 38.3 & 1.5 & 397.1 & 6.5 \\
\hline \multirow[t]{2}{*}{ Yamasa } & 3 & 29.4 & 8.8 & 8.5 & 2.1 & 7.3 & 18.1 & 1.9 & 465.6 & 6.9 \\
\hline & 10 & 13.1 & 5.1 & 8.8 & 4.0 & 2.4 & -0.4 & 1.4 & 639.7 & 5.7 \\
\hline
\end{tabular}

River basin could not be obtained at the time of this study. Thus, no data was prepared in the GIS database.

\section{RESULTS AND DISCUSSIONS}

\subsection{Water Quality at Dam Sites}

The water quality in two artificial reservoirs at the Fube and Yamasa dam sites were measured at three depths (Table 2). As the capacities of both reservoirs are less than 10 million $\mathrm{m}^{3}$, the reservoirs belong to the river category in Japan.

The maximum Chl- $a$ concentration, $7.3 \mu \mathrm{g} \cdot \mathrm{L}^{-1}$, was recorded at a $3 \mathrm{~m}$ depth at the Yamasa reservoir. The highest value recorded at the Fube reservoir $\left(6.9 \mu \mathrm{g} \cdot \mathrm{L}^{-1}\right)$ was also at a $3 \mathrm{~m}$ depth. The lowest values were measured at $10 \mathrm{~m}$ depths for both dam reservoirs, $1.7 \mu \mathrm{g} \cdot \mathrm{L}^{-1}$ at Fube and $2.4 \mu \mathrm{g} \cdot \mathrm{L}^{-1}$ at Yamasa, respectively. As average values of Chl- $a$ concentrations were $4.5 \mu \mathrm{g} \cdot \mathrm{L}^{-1}$ at Fube and 4.1 at Yamasa, both reservoirs are considered to be mesotrophic (OECD, 1982).

As $\mathrm{pH}$ values for the Fube and Yamasa reservoirs exceeded 7 at all depths, the alkaline state of the water is confirmed. The alkaline state was stronger in the Fube reservoir than in the Yamasa reservoir. The $\mathrm{pH}$ values at a depth of 10 $\mathrm{m}$ in both reservoirs were higher than those at $0.5 \mathrm{~m}$. No photosynthesis would occur at this depth. The $\mathrm{pH}$ values at a depth of $10 \mathrm{~m}$ were higher than those at a depth of $0.5 \mathrm{~m}$ because of vertical mixing. Vertical mixing due to heavy rain two weeks previous is considered to be the reason for the small vertical variation in $\mathrm{pH}$ values.

Water temperature and DO concentrations decreased with depth from 0.5 to $10 \mathrm{~m}$ in the Fube reservoir. In addition, water temperature and DO concentration dramatically dropped to their lowest values at a $10 \mathrm{~m}$ depth in the Yamasa reservoir. The DO concentration is low when the pollution from organic matter is considerable. The SS concentration in both reservoirs increased with water depth. It is considered that SS in water began to settle gradually after heavy rain. This means that water quality characteristics at each depth in the reservoirs become complex in a transitional period.

Biodegradation ability was calculated using the DOC concentrations measured before and after the 100 day decomposition experiment. This value is an index of how much persistent organic matter in the water can be broken down under a given condition. The biodegradation ability for both dams decreased with depth from 0.5 to $10 \mathrm{~m} .32 .8 \%$ in the Fube reservoir and $38.3 \%$ in the Yamasa reservoir were seen at a $1 \mathrm{~m}$ depth and $8.4 \%$ in the Fube reservoir and $-0.4 \%$ in the Yamasa reservoir were seen at a $10 \mathrm{~m}$ depth. It seems there are relatively large amounts of easily decomposable organic matter in the upper layer and more persistent organic matter at depth.

Table 3. N/P Ratios for Fube and Yamasa Dams

\begin{tabular}{|c|c|c|c|}
\hline Dam site & Depth (m) & TIN/PO 4 -P & TN/TP \\
\hline \hline & 0.5 & 20.0 & 30.0 \\
\hline Fube & 3 & 16.0 & 27.0 \\
\hline & 10 & 44.0 & 51.0 \\
\hline Yamasa & 0.5 & 66.0 & 61.0 \\
\hline & 3 & 106.0 & 67.0 \\
\hline
\end{tabular}


Table 4. Average Water Quality in the Basin

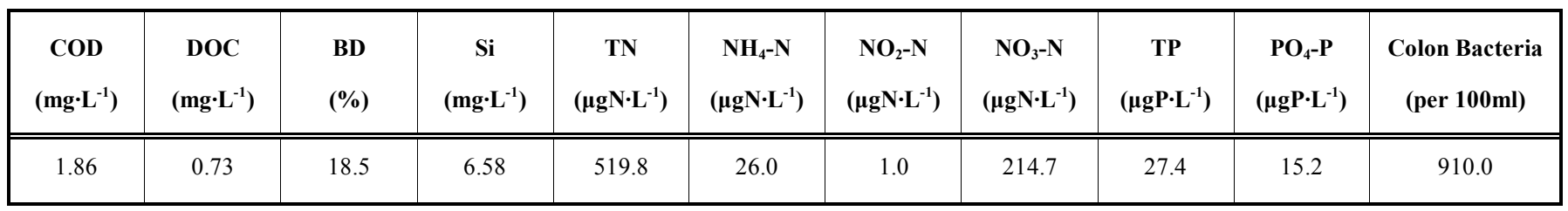

As the average concentrations of TN were about 494.7 $\mu \mathrm{g} \cdot \mathrm{L}^{-1}$ in the Fube reservoir and $500.8 \mu \mathrm{g} \cdot \mathrm{L}^{-1}$ in the Yamasa reservoir, it is possible for Lake Nakaumi to be eutrophic and have a TN concentration higher than the environmental standard of $0.4 \mathrm{mg} \cdot \mathrm{L}^{-1}$.

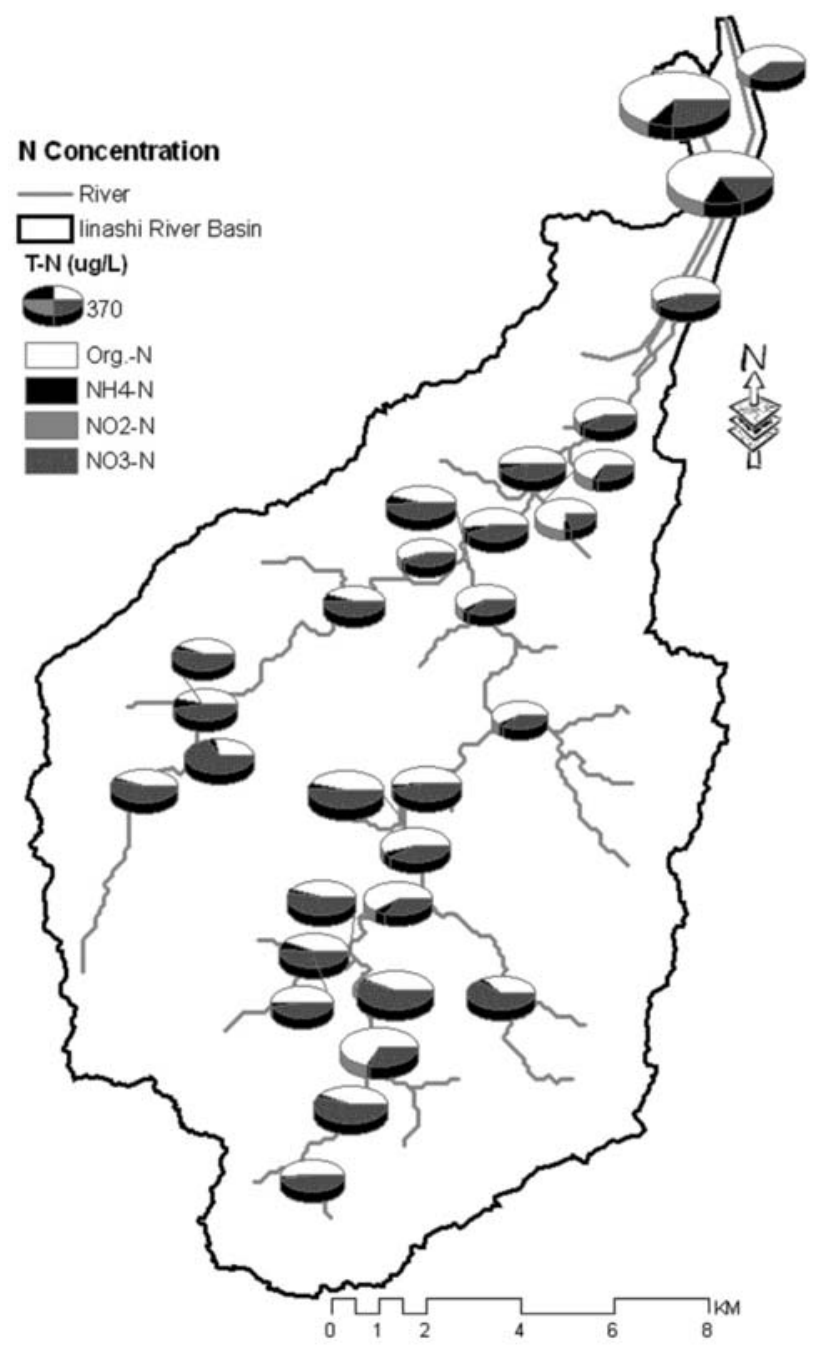

Fig. (2). Composition of total nitrogen at each sampling point.

$\mathrm{N} / \mathrm{P}$ ratios are an index of eutrophication and are shown in Table 3. Both the ratios of TIN/PO $-\mathrm{P}$ and TN/TP were largest at a $10 \mathrm{~m}$ depth in the dam reservoirs. It was thus clarified that phosphorus limits eutrophication in both dam reservoirs because the ratios were over 20 , especially at depth.

\subsection{Water Quality in the Basin}

Average values for several water quality parameters are presented in Table 4. It is considered the concentrations of water quality parameters in the Iinashi River basin were relatively low. However, even an average value of TN concentration exceeded the environmental standard for Lake Nakaumi. The TN was on average $46 \%$ inorganic and $54 \%$ organic nitrogen. Phosphorus was about $56 \%$ inorganic and about $44 \%$ organic. By the way, $\mathrm{NO}_{2}-\mathrm{N}$ concentration at some observed points showed under a detection limit $(<1$ $\left.\mu \mathrm{gN} \cdot \mathrm{L}^{-1}\right)$. Thus, in this case, the value was treated as zero when the average $\mathrm{NO}_{2}-\mathrm{N}$ concentration was calculated.

The composition of total nitrogen at each sampling point is shown in Fig. (2). The concentration in the basin did not differ greatly at each observation point except for the downstream of the basin. A high concentration of nitrogen was observed at the river mouth of the Tayori. TN concentrations of about $1263.6 \mu \mathrm{g} \cdot \mathrm{L}^{-1}$ and $1183.5 \mu \mathrm{g} \cdot \mathrm{L}^{-1}$ were detected at

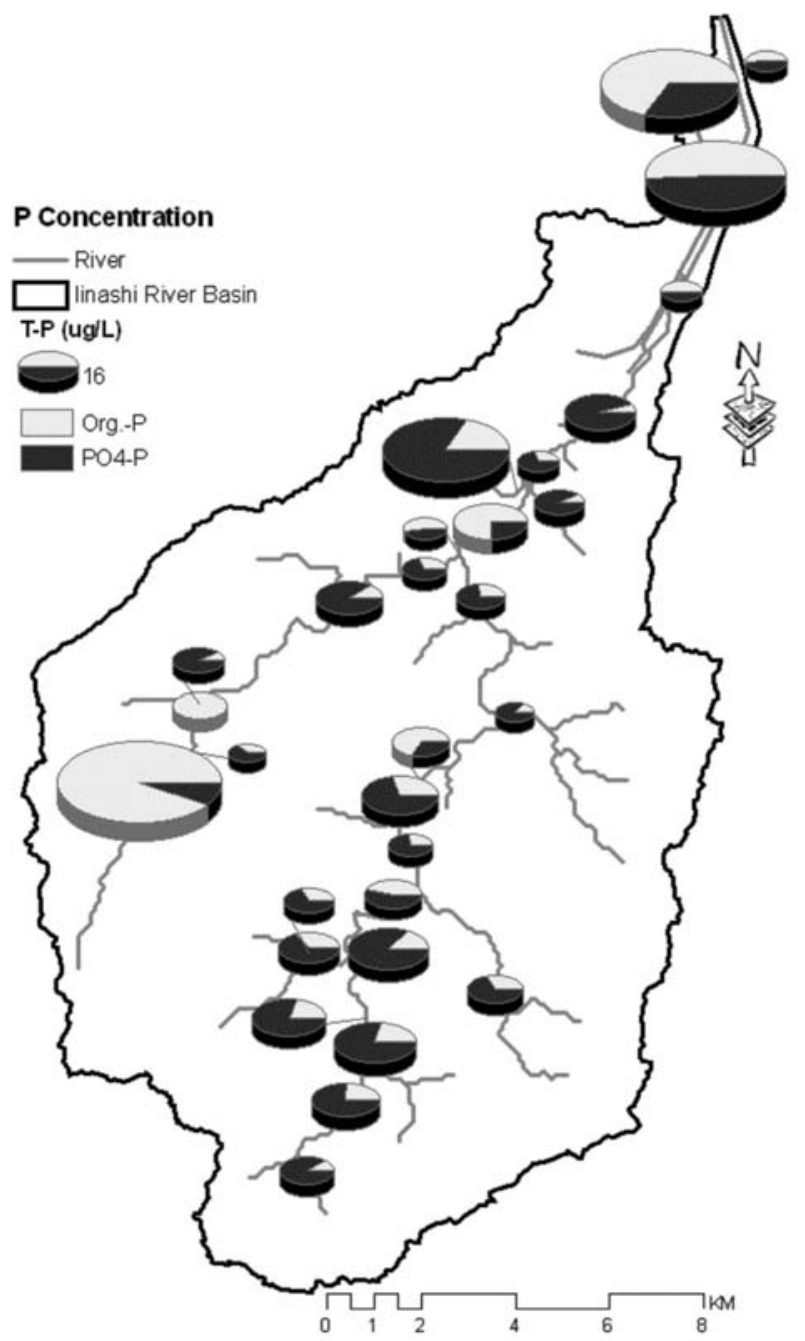

Fig. (3). Composition of total phosphorus at each sampling point. 
observation points $2-1$ and 2-2, respectively. The TN concentration at the river mouth of the Tayori was about 2.5 times that of the Iinashi. The inorganic nitrogen in the TN varied from about $26 \%$ at observation point $1-20$ to $63 \%$ at observation point 1-18.

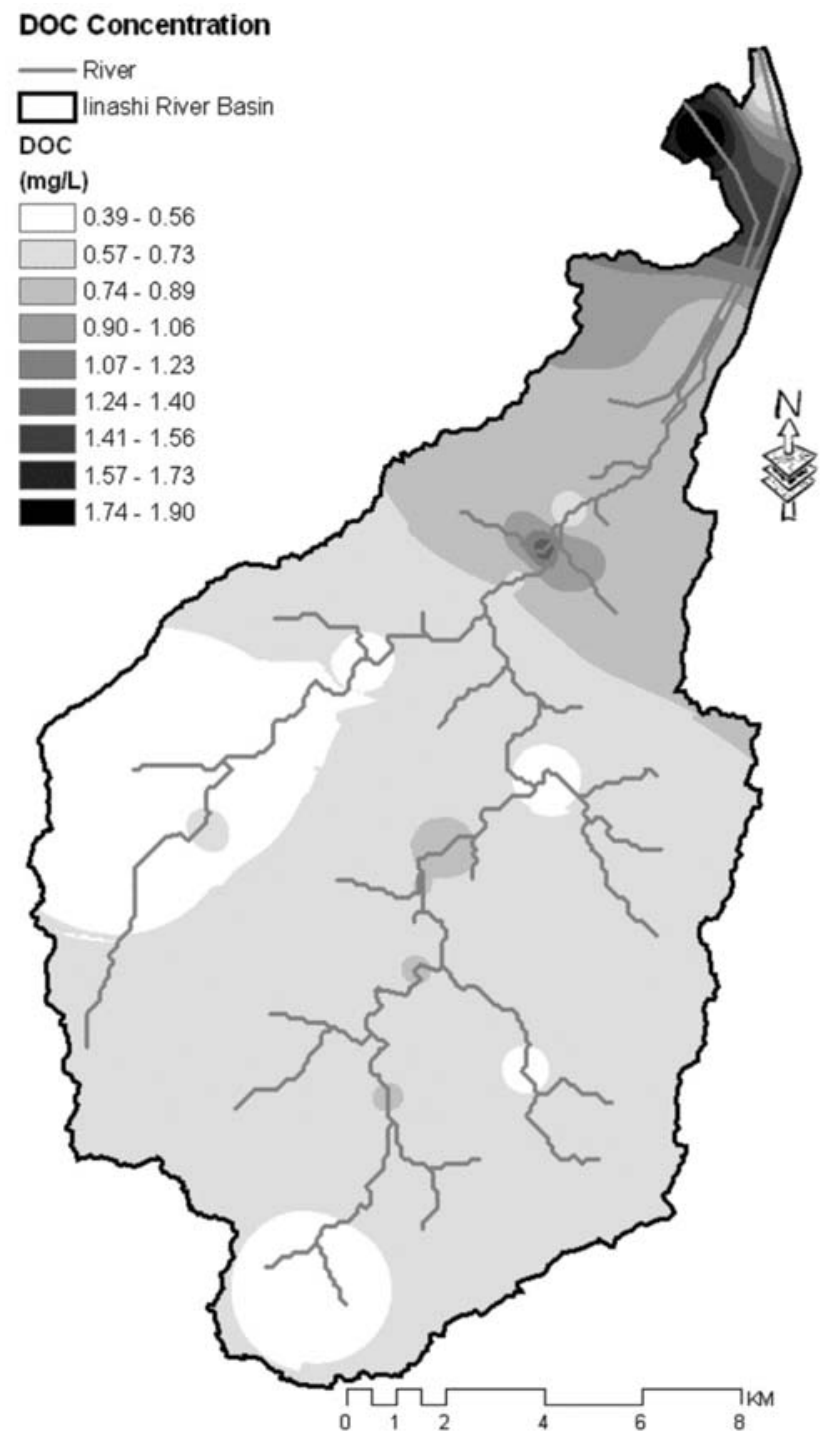

Fig. (4). Spatial distribution of DOC.

A high concentration of phosphorus was observed at not only the town of Hirose and in the downstream of the Tayori, but also in the upstream of the Yamasa (Fig. 3). The organic phosphorus percentage composition of TP was highest at observation point 1-36 in the upstream of the Yamasa, being about $93 \%$. Dissolved phosphorus in the upstream of the Iinashi was more dominant in the TP compared with the upstream of the Yamasa.

The DOC concentration trend changed around Hirose (Fig. 4). A low concentration was observed in the upstream of the basin. Conversely, the DOC concentration increased in the downstream of the basin. In addition, the biodegradation ability was determined from the analysis of the DOC concentration before and after the 100 day decomposition experiment (Fig. 5). According to studies on the origin and dynamics of recalcitrant organic matter in lakes and its ef- fects on lacustrine ecosystems and water quality (NIES, 2001), the biodegradation abilities of river water, sewage treatment water, mountain stream water, percolating water from upland fields and miscellaneous drainage are $27.6 \%$, $18.1 \%, 6.3 \%, 12.4 \%$ and $65.7 \%$ respectively. As the degradation ability in the upstream of the basin was low (6.0 $8.0 \%$ ), it is considered that persistent organic matter flows from the forest basins. Conversely, a high degradation ability of about $47 \%$ was observed in the tributary river at Hirose. From the report by the NIES, it is considered that miscellaneous drainage flows into the river.

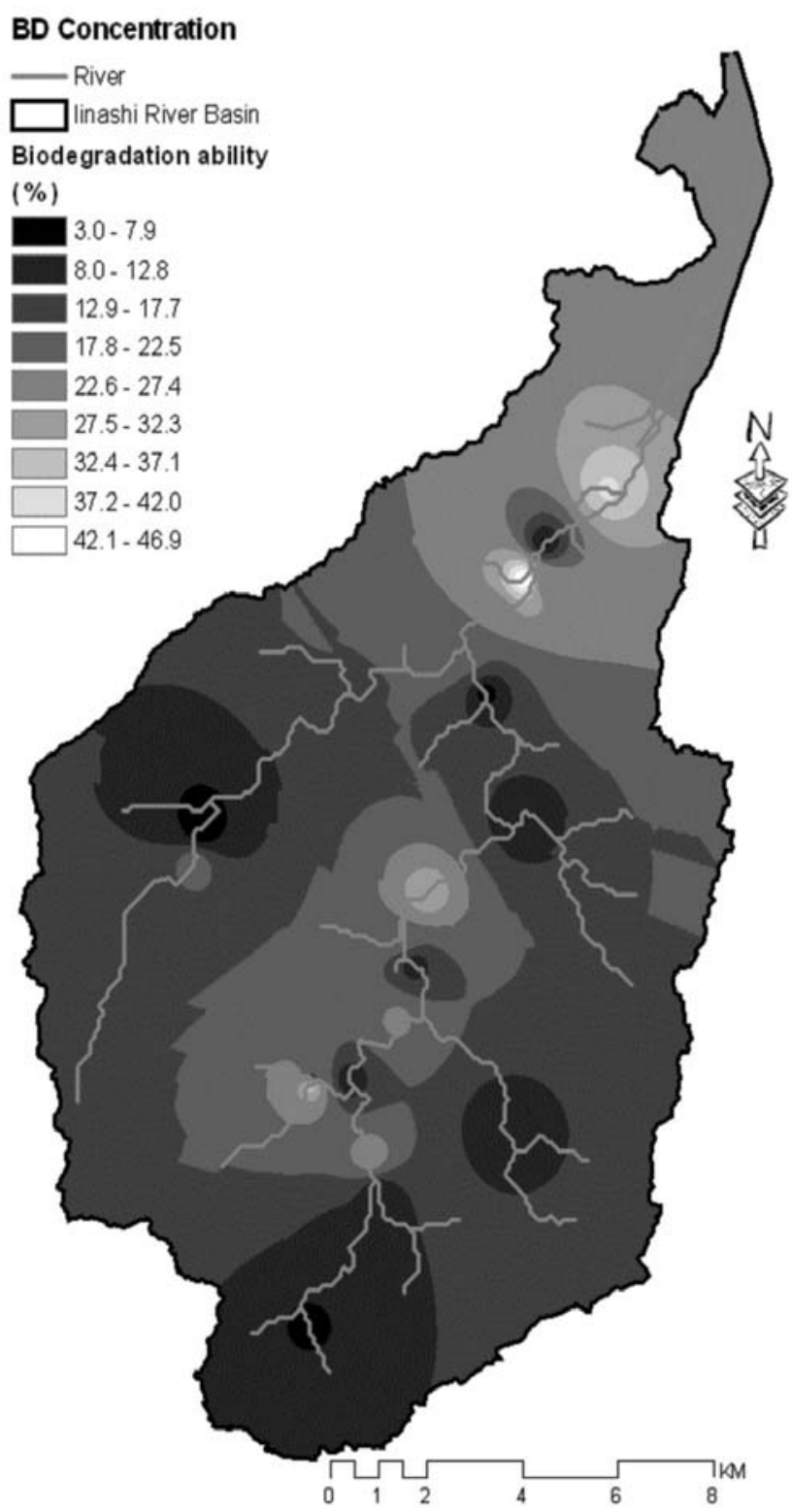

Fig. (5). Spatial distribution of BD.

Coliform bacteria were detected not only in the downstream but also in the upstream of the river (Fig. 6). A high concentration was observed especially in the upstream of the main channel. It is possible the river was polluted by human waste just before water sampling because Coliform bacteria are detected acutely when water is polluted by minute quantities of human waste, or by constant human waste considering a low sewage system adoption ratio. 


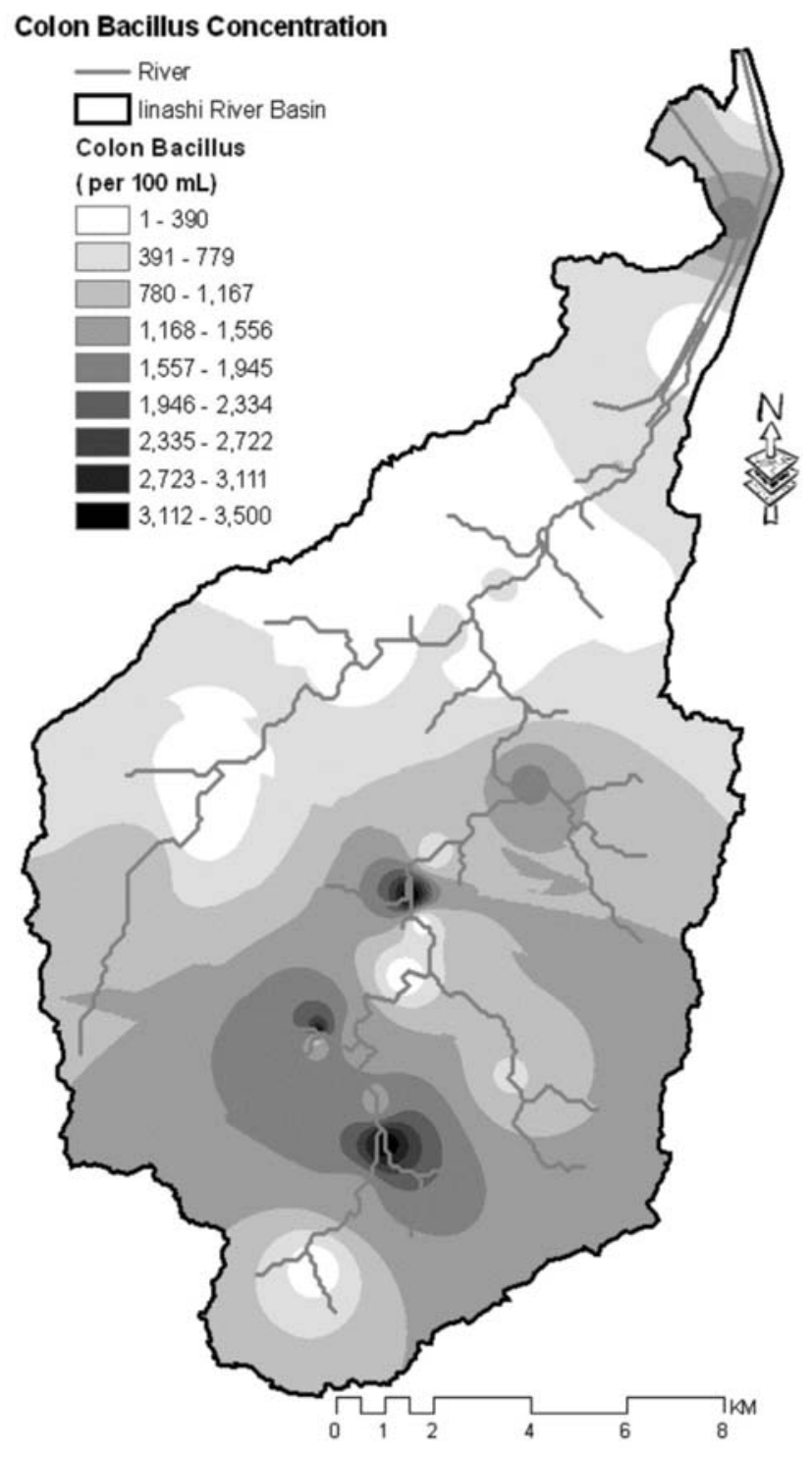

Fig. (6). Spatial distribution of CB.

The spatial distribution of $\mathrm{Si}$ is shown in Fig. (7). Si is supplied by weathering, such as that associated with rain water or river water, and silicate mineral or rock. Si is very common and has an important role in the food chain. However, several researchers reported that $\mathrm{Si}$ concentration decreases from upstream to downstream of a dam (Vörösmarty et al. 1997; Venugopalan et al. 2000). Likewise, Si was observed to decreases slightly from upstream to downstream for the basins in this experiment.

\subsection{Land Use}

The percentage of land used for agriculture in the GIS data is shown in Fig. (8). The percentage varied from $0 \%$ to $69 \%$ in the basin. Especially in the Tayori River basin, there was a high ratio of agricultural land. Relatively high percentages from $6 \%$ to $13 \%$ were seen around not only Hirose but also in the upstream of the Iinashi River. Agricultural land percentages from $0 \%$ to $5 \%$ were dominant in the basin.

The relationship between residential area and population in the basin is shown in Fig. (9). As it is very difficult to obtain population data for the Tayori River, the data for the basin was not prepared in the GIS database. The percentage of residential area was between $0 \%$ and $20.1 \%$ in the basin. Almost all sub basins were $0 \%$ to $0.5 \%$ residential except for the downstream of the Iinashi River and some sub basins located in the upstream of the Iinashi River. The population is very much concentrated in downtown Hirose. However, the population is spread all over the basin along rivers.

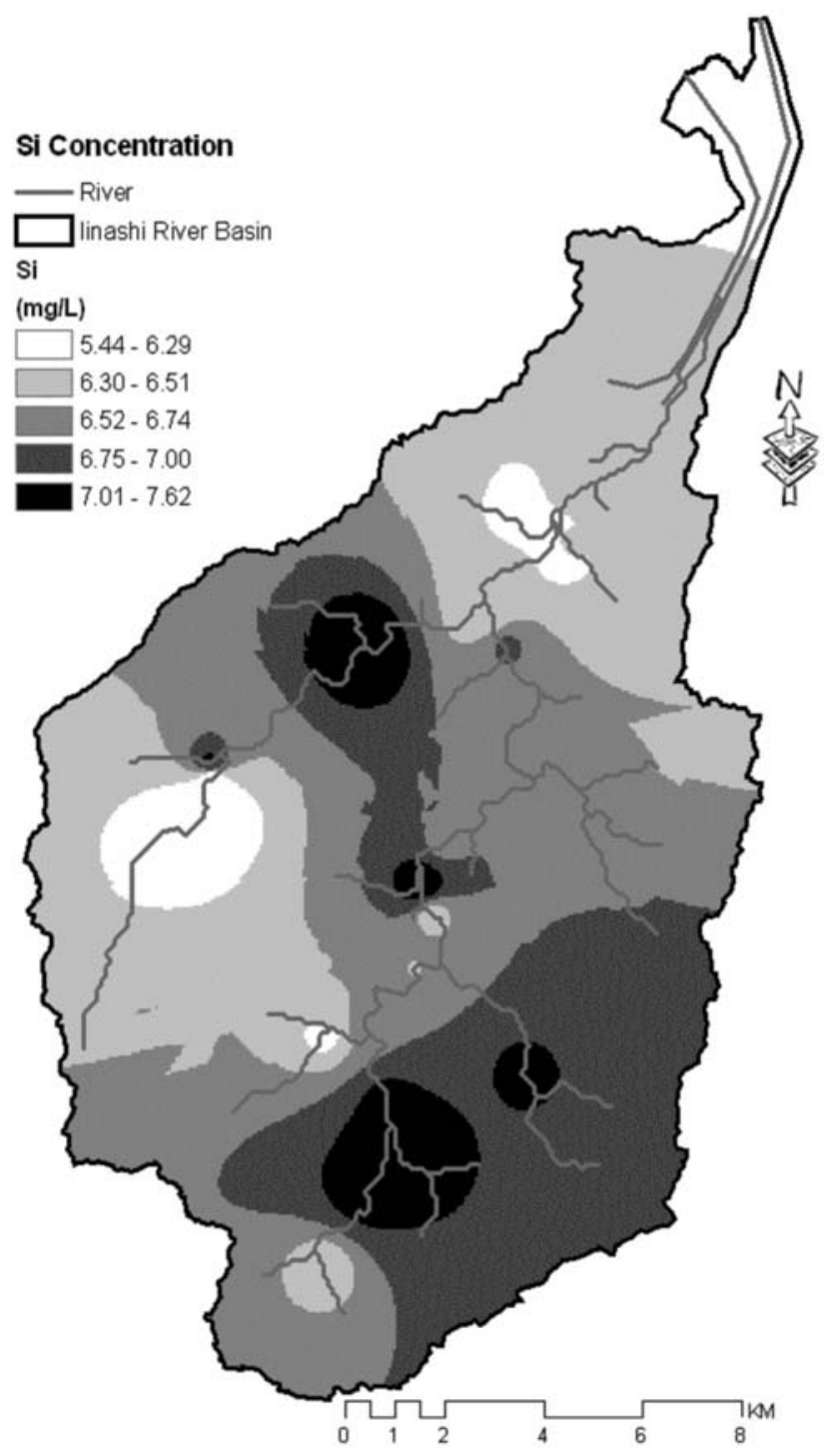

Fig. (7). Spatial distribution of Si.

The forest area ratio and breakdown of forest types are shown in Fig. (10). There is a recognizable spatial distribution of forest in the basin. As there is much habitation along the rivers, the forest area ratio decreased in the central part of the basin. However, the ratio was over $50 \%$ for almost all the basin. Not only artificial forests but also natural forests remain to a large extent. In addition, a few bamboo groves remain in the Yamasa River basin.

\subsection{Load Units}

Load units were calculated from concentration data and discharge data for several parameters as shown in Fig. (11). Fig. (11) shows variations in the load unit for small watersheds. The $\mathrm{x}$-axis represents each small sub basin watershed 


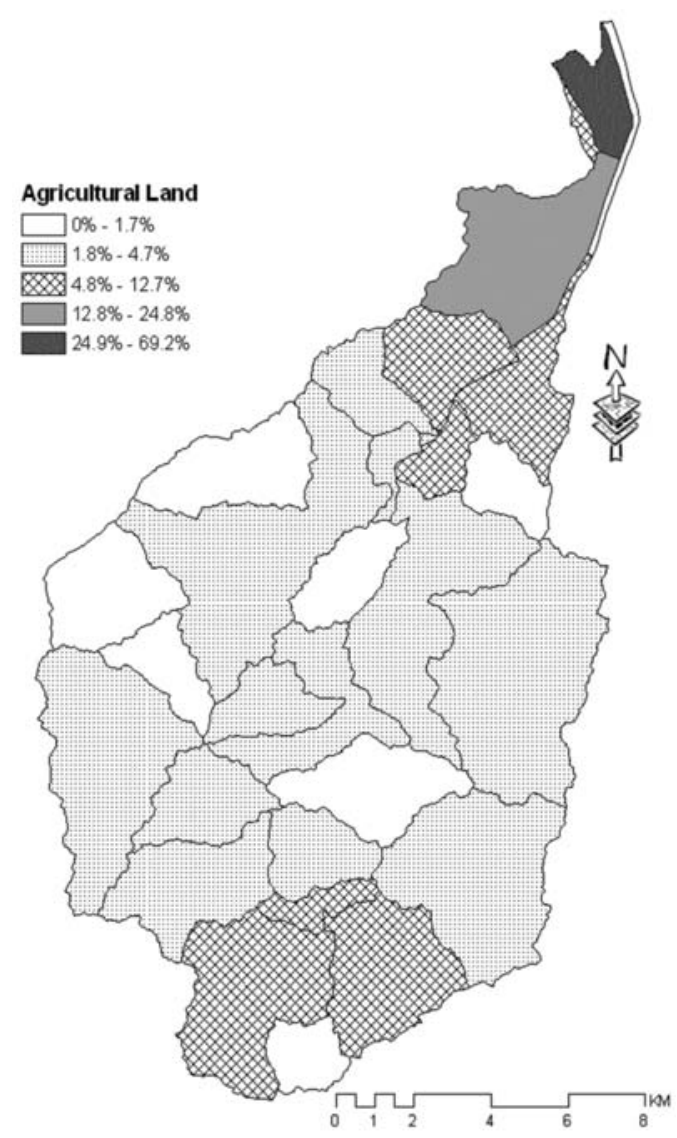

Fig. (8). Agricultural land in each sub basin.

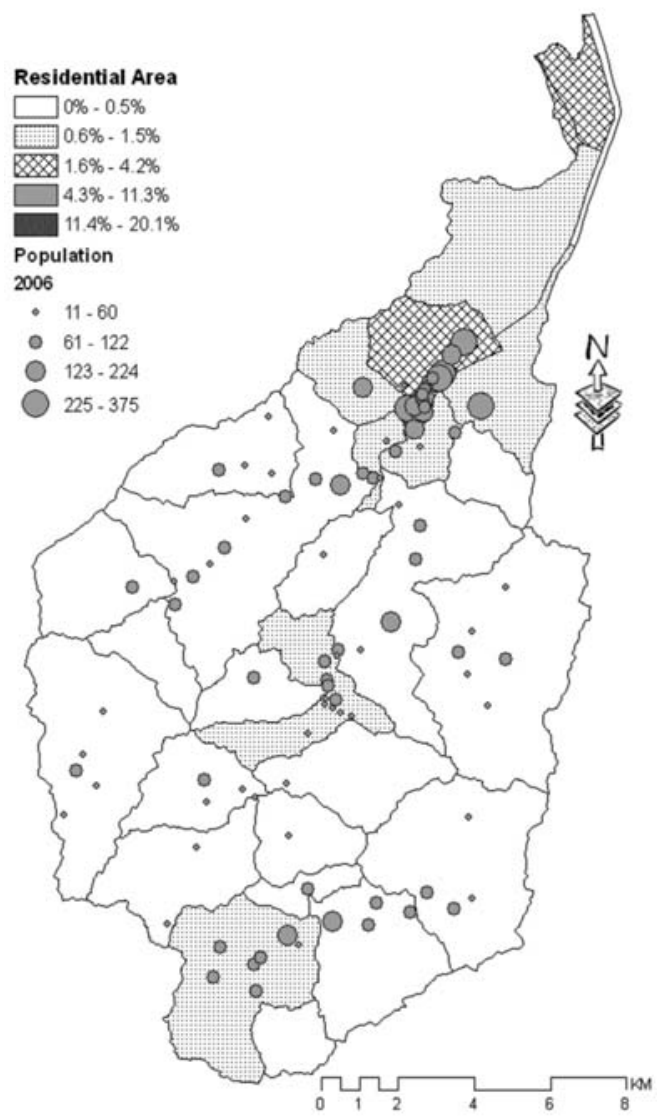

Fig. (9). Residential areas and population. located from the upstreams to the downstreams of the Iinashi and Yamasa Rivers, and each sub basin is independent. In other words, small watersheds were selected using the criteria that there is no inflow from other watersheds. Watersheds 1 to 8 are located in the upstream of the Iinashi River, watersheds 9 to 11 are in the upstream of the Yamasa River, and the remaining watersheds are in the downstream of the Iinashi River. The graphs in the figure show the ratios of forest and agricultural areas in target small watersheds and load units of the COD, TN and TP. Load units were calculated by two methods. One method was a calculation using the results of our investigation, and the other method was a calculation using the L-Q equation for the load unit estimations of the forest area defined by Shimane Prefecture. In addition, maximum and minimum values for each parameter of the forest area were quoted from the literature (Takeda, 2001). As shown in the figure, forest occupied over $80 \%$ of all watersheds except for watersheds 6 and 8, and over $60 \%$ of watersheds 6 and 8 . The proportion of agricultural area is very small and varied from $0.94 \%$ to $8.29 \%$.

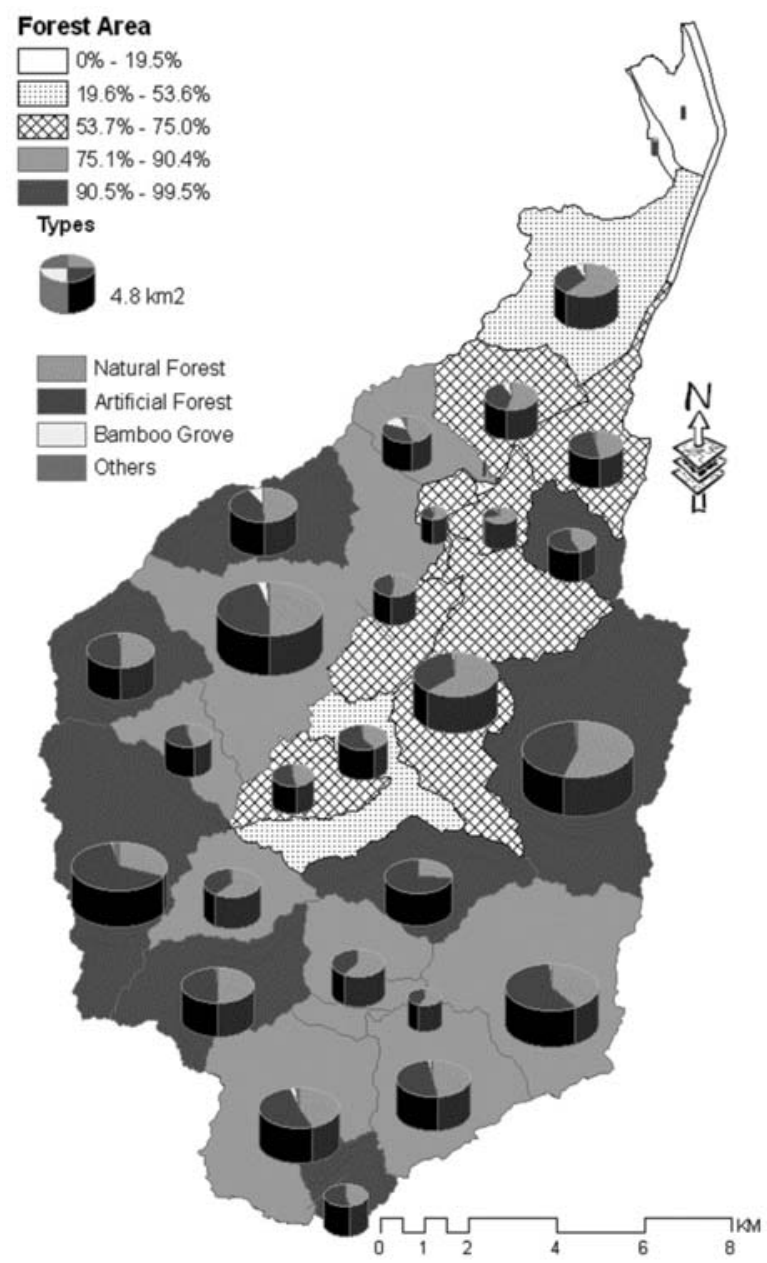

Fig. (10). Forest areas and types.

Load units for all parameters varied for each watershed regardless of the similar components of land use. The load unit of the COD changed from 34.94 (watershed 13) to 129.46 (watershed 2) $\mathrm{g} \cdot \mathrm{ha}^{-1} \cdot \mathrm{day}^{-1}$, that of TN from 7.57 (watershed 12) to 35.15 (watershed 2) $\mathrm{g} \cdot \mathrm{ha}^{-1} \cdot \mathrm{day}^{-1}$, and that of TP from 0.19 (watershed 7) to 1.78 (watershed 2) $\mathrm{g} \cdot \mathrm{ha}^{-1} \cdot \mathrm{day}^{-}$ 1 . The TP load for watershed 9 was discounted because 

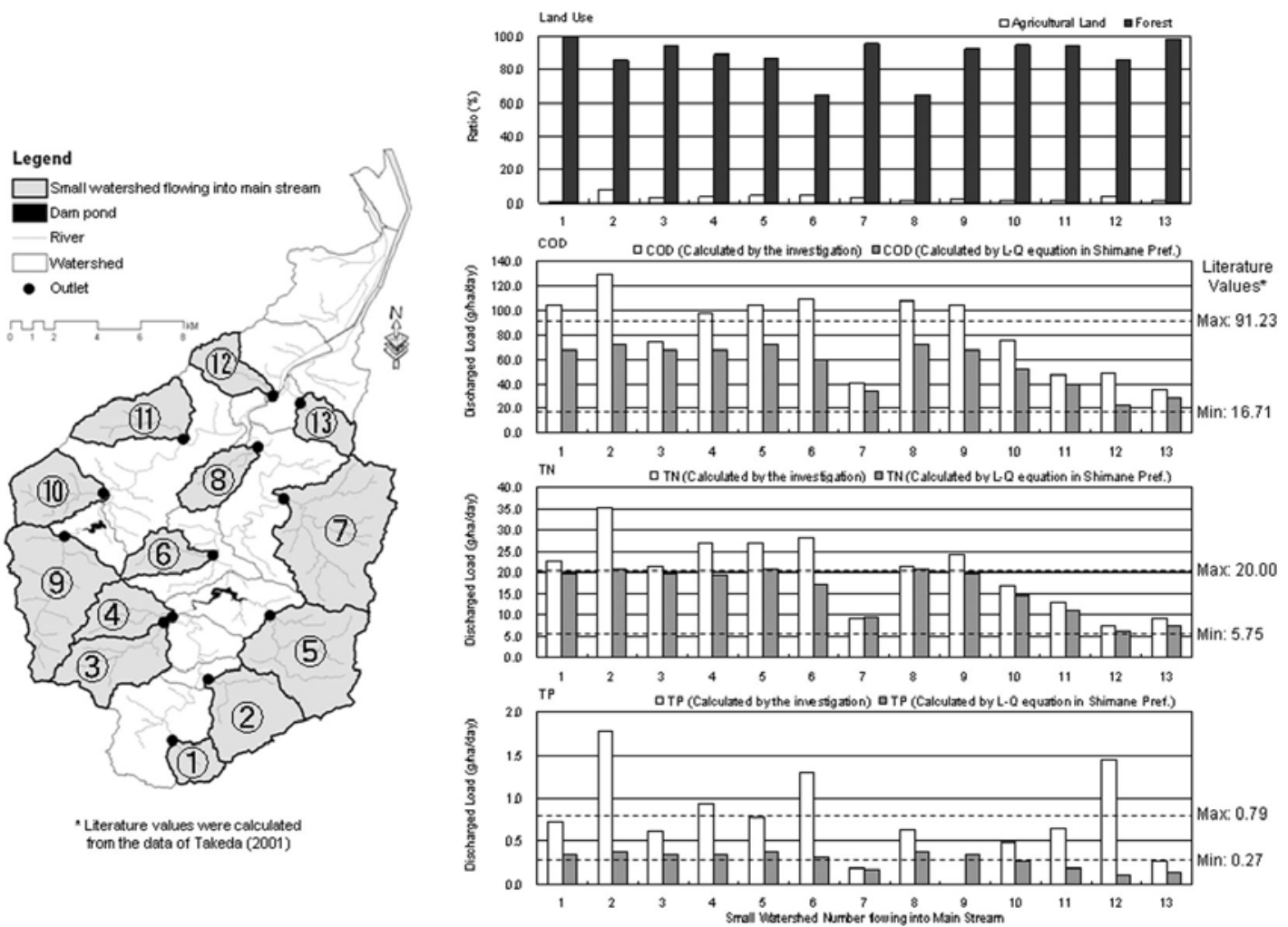

Fig. (11). Difference in discharged load units for each small watershed.

it was an outlier. Compared with load units calculated using the L-Q equation, almost all values calculated using the results of the investigation were higher, but trends of changes in load units are also represented by L-Q equations. COD load units for watersheds $1,2,4,5,6,8$ and 9 exceeded the maximum value in the literature of $91.23 \mathrm{~g} \cdot \mathrm{ha}^{-1} \cdot \mathrm{day}^{-1}$. TN load units for watersheds $1,2,3,4,5,6,8$ and 9 exceeded $20.0 \mathrm{~g} \cdot \mathrm{ha}^{-1} \cdot$ day $^{-1}$ and TP load units for watersheds 2, 4, 6 and 12 exceeded $0.79 \mathrm{~g} \cdot \mathrm{ha}^{-1} \cdot \mathrm{day}^{-1}$. In addition, there is a trend for load units in the downstream of the Iinashi River (watersheds 12 and 13) to be lower for COD, TN and TP, except for TP in watershed 12, compared with load units in the upstream of the basin. Though it is very difficult to determine the reasons for the spatial differences in load units, the ratios of agricultural and residential areas are one because the percentage of agricultural area exceeded $4.5 \%$ in watersheds 2 and 6 and these watersheds had higher load units. Moreover, the TP concentration in watershed 12 exceeded the maximum value, $0.79 \mathrm{~g} \cdot \mathrm{ha}^{-1} \cdot \mathrm{day}^{-1}$. It is considered that the $0.87 \%$ residential area, which was the highest value in the target small watershed, was a reason for the high load units.

Finally, pollutant loads flowing from upstream to downstream were calculated as shown in Fig. (12). As there are no discharge data for around the river mouth (1-1, 1-2) and Tayori River, the loads were not calculated in this paper. These values were calculated at observation points 1-3, 1-5 and 1-31. Observation points 1-5 and 1-31 are located immediately before the confluence of the upstreams of the Iinashi and Yamasa Rivers. Observation point 1-3 is located in the downstream of the Iinashi River and is the final point of discharge data. Because there is no inflow from another river after observation point 1-3 for the Iinashi River, the calculated load unit at 1-3 is not affected by the inflow of a pollutant load from another river until the river mouth. Though the Yamasa River basin has a higher percentage of forest area $(91.5 \%)$, lower percentage of agricultural land $(2.3 \%)$ and lower population density $\left(24\right.$ people $\left.\cdot \mathrm{km}^{-2}\right)$ than the upstream Iinashi River basin as shown in Table 5, discharged loads from observation point 1-31 were higher than those from observation point 1-5. The discharged loads from observation point $1-3$ were $53.2 \mathrm{~g} \cdot \mathrm{ha}^{-1} \cdot \mathrm{day}^{-1}$ of SS, $45.4 \mathrm{~g} \cdot \mathrm{ha}^{-}$ ${ }^{1} \cdot$ day $^{-1}$ of COD, $20.9 \mathrm{~g} \cdot \mathrm{ha}^{-1} \cdot \mathrm{day}^{-1}$ of DOC, $8.1 \mathrm{~g} \cdot \mathrm{ha}^{-1} \cdot \mathrm{day}^{-1}$ of POC, $16.3 \mathrm{~g} \cdot \mathrm{ha}^{-1} \cdot \mathrm{day}^{-1}$ of TN, $5.0 \mathrm{~g} \cdot \mathrm{ha}^{-1} \cdot \mathrm{day}^{-1}$ of DON, 1.3

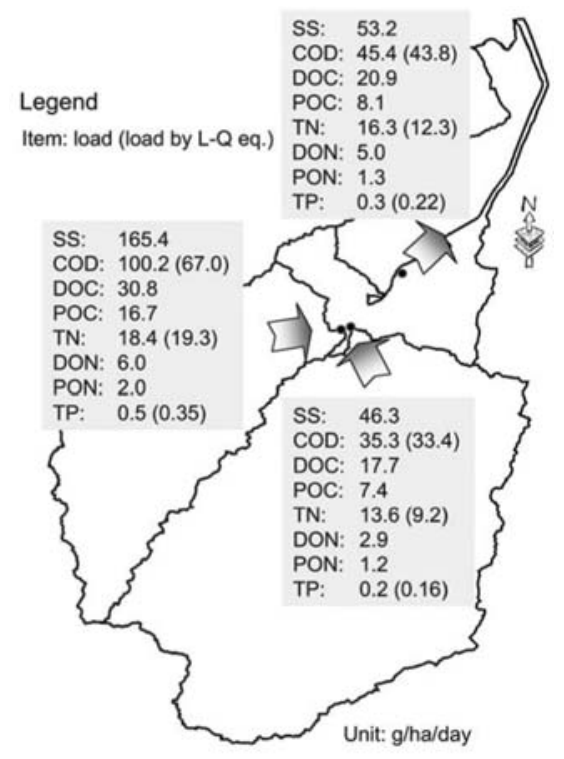

Fig. (12). Pollutant loads from upstream to downstream. 
Table 5. Forest Area Percentage, Agricultural Area Percentage and Population Density

\begin{tabular}{|c|c|c|c|}
\hline & Forest area (\%) & Agricultural area (\%) & Population density (people·km ${ }^{-2}$ ) \\
\hline \hline Upstream of Iinashi River basin & 89.1 & 4.3 & 26 \\
\hline Yamasa River basin & 91.5 & 2.3 & 24 \\
\hline Downstream of Iinashi River basin & 60.6 & 15.8 & - \\
\hline
\end{tabular}

$\mathrm{g} \cdot \mathrm{ha}^{-1} \cdot \mathrm{day}^{-1}$ of PON, and $0.3 \mathrm{~g} \cdot \mathrm{ha}^{-1} \cdot \mathrm{day}^{-1}$ of TP respectively.

\section{CONCLUSION}

Water quality was investigated to determine the characteristics of the water environment in the basin. A GIS database was created to consider the relationship between land characteristics and water environment. This research is summarized as follows.

1. From the Chl- $a$ concentration, it is considered the dams of Fube and Yamasa were mesotropic reservoirs. Considering of N/P ratio, phosphorus limits eutrophication.

2. The concentrations of water quality parameters in the Iinashi River basin were relatively low at almost all sampling points. The average concentrations of each parameter are $1.86 \mathrm{mg} \cdot \mathrm{L}^{-1}$ of COD, $0.73 \mathrm{mg} \cdot \mathrm{L}^{-1}$ of DOC, $18.5 \%$ of $\mathrm{BD}, 6.58 \mathrm{mg} \cdot \mathrm{L}^{-1}$ of $\mathrm{Si}, 519.8 \mu \mathrm{gN} \cdot \mathrm{L}^{-1}$ of $\mathrm{TN}, 26.0$ $\mu \mathrm{gN} \cdot \mathrm{L}^{-1}$ of $\mathrm{NH}_{4}-\mathrm{N}, 1.0 \mu \mathrm{gN} \cdot \mathrm{L}^{-1}$ of $\mathrm{NO}_{2}-\mathrm{N}, 214.7 \mu \mathrm{gN} \cdot \mathrm{L}^{-1}$ of $\mathrm{NO}_{3}-\mathrm{N}, 27.4 \mu \mathrm{gP} \cdot \mathrm{L}^{-1}$ of $\mathrm{TP}$, and $15.2 \mu \mathrm{gP} \cdot \mathrm{L}^{-1}$ of $\mathrm{PO}_{4^{-}}$ $\mathrm{P}$.

3. Some substances such as phosphorus and colon bacteria had high concentrations not only at Hirose but also in the upstream of the basin.

4. Information for the load units discharged from small watersheds was obtained. Load units varied regardless of similar land uses in the basin.

5. Discharged loads from observation point 1-31 in the Yamasa River basin were higher than from observation point 1-5 in the upstream of the Iinashi River basin regardless of the high percentage of forest area (91.51\%), low percentage of agricultural land $(2.3 \%)$ and low population density $\left(24\right.$ people $\left.\cdot \mathrm{km}^{-2}\right)$.

6. The discharged loads from observation point 1-3 were determined as $53.2 \mathrm{~g} \cdot \mathrm{ha}^{-1} \cdot \mathrm{day}^{-1}$ of SS, $45.4 \mathrm{~g} \cdot \mathrm{ha}^{-1} \cdot \mathrm{day}^{-1}$ of COD, $20.9 \mathrm{~g} \cdot \mathrm{ha}^{-1} \cdot \mathrm{day}^{-1}$ of DOC, $8.1 \mathrm{~g} \cdot \mathrm{ha}^{-1} \cdot \mathrm{day}^{-1}$ of POC, $16.3 \mathrm{~g} \cdot \mathrm{ha}^{-1} \cdot \mathrm{day}^{-1}$ of TN, $5.0 \mathrm{~g} \cdot \mathrm{ha}^{-1} \cdot$ day $^{-1}$ of DON, $1.3 \mathrm{~g} \cdot \mathrm{ha}^{-}$ ${ }^{1} \cdot$ day $^{-1}$ of PON, and $0.3 \mathrm{~g} \cdot \mathrm{ha}^{-1} \cdot$ day $^{-1}$ of TP.

From this research, an outline of the water environment for the Iinashi River basin was clarified for the first time. Moreover, a prototype GIS database was built for the basin. With the development of an integrated approach for water environment management in the basin, it will be necessary to store such research results to estimate the quantitative impact on the lake.

\section{ACKNOWLEDGEMENTS}

This work was supported by intensive field work and water quality analysis by students at Shimane University. We would like to express our gratitude to Mr. Ken-ichiro Kido, Mr. Tokusei Matsushima, Ms. Makiko Sakurai, Mr.
Masaaki Hirao, Mr. Kiyoshi Fujii, Mr. Satoshi Ishida, Mr. Ken-ichi Sawata and Mr. Yuya Hirai. We also wish to convey our special thanks to Mr. Ko Fujiyama of the Shimane Prefecture Mountainous Region Research Center who collected GIS and statistical data. The statistical population database and forest data were obtained from the Shimane Prefecture Mountainous Region Research Center and Department of Agriculture, Forestry and Fisheries in Shimane Prefecture, respectively. Aerial photographs were obtained from Shimane Prefecture. This research was supported by a Grantin-aid of the Shimane University Priority Research Project.

\section{REFERENCES}

[1] Bendschneider K, Robinson RJ. A new spectrophotometric method for the determination of nitrite in sea water. J.Mar.Res 1952,11: 8796.

[2] Ishitobi Y, Kawatsu M, Kamiya H, Hayashi K, Esumi H. Estimation of water quality and nutrient loads in the Hii River by semidaily sampling, Jpn.J.Limnol. 1988, 49 (1): 11-17.

[3] Menzel DW, Corwin N. The measurement of total phosphorus in seawater based on the liberation of organically bound fraction by persulfate oxidation. Limnol. Oceanogr. 1965, 10: 280-282.

[4] Murphy J, Riley JP. A modified single solution method for the determination of phosphate in natural waters. Anal.Chim.Acta. 1962, 27: 31-36.

[5] NIES. Report of Special Research from the National Institute for Environmental Studies, Japan, 2001, 1-30.

[6] Nonaka T, Matsunaga T, Hoyano A. Validation of Water Quality Data Measured Using Automatic Monitoring Sensor in Lake Shinj and Lake Nakaumi, Laguna 2003, 10: 101-107.

[7] OCDE. Eutrophication of waters - Monitoring assessment and control -, OECD publications 1982; p154, ISBN 92-64-12298-2.

[8] Sagi T. Determination of ammonia in sea water by the indophenol method and its application to the coastal and off-shore waters. Limnol.Oceanogr.1966, 13: 440-447.

[9] Saijo Y, Mitamura O. Limnological Analysis. Kodansha Ltd: Tokyo 1995; p230, ISBN 4-06-153934-5. (In Japanese).

[10] Sakuno Y, Nakayama D, Matsunaga T. Water Quality Mapping in Lake Shinji and Lake Nakaumi Using Satellite Remote Sensing Data (Part 2), Laguna 1998, 6: 205-216.

[11] Sakuno Y, Yamamoto M, Yoshida T. Estimation of Water Temperature and Turbidity in Lake Shinji and Lake Nakaumi Using ASTER Data, 2000-2002, Laguna 2003, 10: 65-72.

[12] Seike Y, Kondo K, Mitamura O, Ueda S, Senga Y, Fukumori R, Fujinaga K, Takayasu K, Okumura M. Seasonal variation in nutrients and chlorophyll a in the stratified brackish lake Nakaumi, Japan, Verh. Internat. Verein. Limnol. 2006, 29: 1959-1965.

[13] Senga Y, Seike Y, Mochida K, Fujinaga K, Okumura M. Nitrous oxide in brackish Lakes Shinji and Nakaumi, Japan, Limnology 2001, 2 (2): 129-136.

[14] SCOR/ UNESCO. Report of SCOR-UNESCO working group 17 on determination of photosynthetic pigments in sea water, Monogr. Oceanogr. Methodol. 1966, 1: 9-18.

[15] Takeda I, Fukushima A, Mori Y. An estimation of runoff loads of pollutants from River Hii to Lake Shinji, Laguna 1996, 3: 91-96.

[16] Takeda I. Basic knowledge of water and water environment (in Japanese), Ohmsha 2001; p198, ISBN 4-274-02462-8.

[17] Venugopalan I, Christoph H, Petra S. Hydrological Alterations and Marine Biogeochemistry: A Silicate Issue?, BioScience 2000, 50 (9): 776-782.

[18] Vörösmarty CJ, Sharma KP, Fekete BM, Copeland AH, Holden J, Marble J, Lough JA. The Storage and Aging of Continental Runoff in Large Reservoir Systems of the World. Ambio. 1997, 26 (4): 210-219.

[19] Wood ED, Armstrong FAJ, Richards FA. Determination of nitrate in seawater by cadmium-copper reduction to nitrite. J.Mar.Biol.Assoc.U.K. 1967, 47: 23-31. 